\title{
Pengaruh Body Shaming Terhadap Kecenderungan Anorexia Nervosa Pada Remaja Perempuan di Surabaya
}

\author{
Tri Indah Sari ${ }^{1}$, Rezkiyah Rosyidah ${ }^{2}$ \\ ${ }^{1}$ Program Studi Psikologi, Fakultas Ilmu Sosial dan Ilmu Budaya \\ Universitas Trunojoyo Madura \\ 1isari7589@gmail.com
}

\begin{abstract}
There are many dramatic changes in adolescence, one of them is the physical changes in which adolescent girls are less satisfied with their bodies due to increased amount of fat. There is an assumption that having a thin body will be easier to adapt to the social environment, influencing adolescents in making a decision to go on a diet even though it causes a tendency to anorexia nervosa. This research was conducted to knowing the effect of body shaming on the tendency of anorexia nervosa in adolescent girls in Surabaya. This study uses a quantitative approach where the respondents in this study were adolescent girls who experienced the tendency of anorexia nervosa in the city of Surabaya with a total of 349 respondents. The instruments in this study were the body shaming scale and the tendency scale for anorexia nervosa. This study used to simple linear regression test to analyze data (with SPSS 24 for windows program). The results of the study show the value of $F=54.172 ; P=0.00$, and $R=0.135$. This means that there is an effect of body shaming on the tendency of anorexia nervosa in teenage girls in Surabaya.
\end{abstract}

Keywords: Body Shaming, Anorexia Nervosa, Adolescent Girls, Surabaya

\begin{abstract}
Abstrak
Banyak perubahan dramatis di usia remaja, salah satunya adalah perubahan fisik dimana remaja perempuan kurang puas dengan tubuhnya terkait dengan meningkatnya jumlah lemak. Adanya anggapan bahwa memiliki tubuh kurus akan lebih mudah beradaptasi dengan lingkungan sosial, mempengaruhi remaja dalam mengambil suatu keputusan untuk melakukan diet meskipun menimbulkan kecenderungan anorexia nervosa. Penelitian ini dilakukan dengan tujuan untuk mengetahui pengaruh body shaming terhadap kecenderungan anorexia nervosa pada remaja perempuan di Surabaya. Penelitian ini menggunakan pendekatan kuantitatif dimana responden dalam penelitian ini adalah remaja perempuan yang mengalami kecenderungan anorexia nervosa dikota Surabaya dengan jumlah 349 responden. Instrumen dalam penelitian ini adalah skala body shaming dan skala kecenderungan anorexia nervosa. Analisis yang digunakan dalam penelitian ini adalah uji regresi linier sederhana dengan bantuan program SPSS 24 for windows dimana hasil penelitian menunjukkan nilai $\mathrm{F}=54,172 ; \mathrm{P}=0,00$, dan $\mathrm{R}=0,135$. Artinya terdapat pengaruh bodyshaming terhadap kecenderungan anorexia nervosa pada remaja perempuan di Surabaya.
\end{abstract}

Kata Kunci : Body Shaming, Anorexia Nervosa, Remaja Perempuan, Surabaya 


\section{Pendahuluan}

Kemajuan teknologi pada saat ini memberikan kemudahan dalam mengakses berbagai informasi dari beragam media, baik melalui media elektronik seperti televisi, hingga melalui perangkat canggih seperti smartphone. Hal tersebut berdampak pada penyebaran infromasi-informasi berupa nilai-nilai yang dengan sangat mudah mempengaruhi sikap dan perspektif masyarakat terhadap sesuatu, termasuk mengenai standar tubuh ideal baik bagi pria maupun wanita.

Iklan cenderung mengarahkan individu untuk membuat standar tubuh ideal seperti yang ditampilkan di iklan. Beberapa iklan selalu menampilkan wanita maupun pria dalam bentuk yang diyakini sebagai standar ideal dari seorang pria ataupun wanita. Pada wanita digambarkan dengan seseorang yang memiliki badan langsing, paha, pinggang, pinggul ramping, dan berkaki jenjang, serta berkulit putih mulus. Sementara itu, pada pria digambarkan dengan seseorang yang memiliki bentuk tubuh yang ramping, berotot, dan sehat (Strandbu \& Kvalem dalam Widiasti, 2016).

Standar ideal tersebut kemudian membentuk citra tubuh di masyarakat, khususnya para remaja (Sakinah, 2018). Menurut Santrock (2011), remaja sangat memperhatikan tubuhnya dan membentuk gambaran tentang tubuhnya. Pada masa remaja ini, terjadi banyak perubahan dramatis, diantaranya perubahan fisik, kognitif, emosional, dan perkembangan sosial (Guindon, 2010). Santrock (2012) menyatakan bahwa pada masa pubertas seorang remaja perempuan merasa kurang puas dengan tubuhnya terkait dengan meningkatnya jumlah lemak. Sebaliknya, hasil yang berbeda terlihat pada seorang remaja laki-laki dimana mereka terlihat lebih puas ketika melewati masa pubertas karena sehubungan dengan meningkatnya massa otot.

Christiani (2015) berpendapat bahwa citra tubuh merupakan bias gender sehingga dapat menyebabkan ketimpangan-ketimpangan dengan adanya citra tubuh ideal yang lebih ditekankan pada wanita daripada pria. Di usianya yang menginjak 12 hingga 21 tahun, remaja mengalami peningkatan kesadaran diri atau disebut egosentrisme yang salah satunya terdiri dari komponen imaginary audience, yaitu keyakinan remaja bahwa orang lain berminat pada dirinya sebagaimana ia berminat pada dirinya sendiri, termasuk juga tingkah laku menarik perhatian atau berusaha untuk diperhatikan, terlihat, serta berada "di panggung" (David Elkind dalam Santrock, 2012). 
Akibatnya, dengan adanya body image ini dapat memungkinkan seseorang untuk melakukan pembandingan keadaan antara dirinya dengan orang lain sehingga menimbulkan rasa malu terhadap tubuhnya sendiri, yang biasa disebut dengan istilah body shame (Damanik, 2018). Body shaming adalah penilaian seseorang mengenai tubuhnya yang menyebabkan timbul perasaan bahwa tubuhnya memalukan karena penilaian dirinya dan orang lain terhadap bentuk tubuh ideal yang tidak sesuai dengan tubuhnya (Damanik, 2018). Bentuk-bentuk body shaming ini sendiri meliputi fat shaming, skinny/thin shaming, rambut tubuh/tubuh berbulu, dan warna kulit (Fauzia \& Rahmiaji, 2019). Menurut Widiasti (2016), remaja seringkali menjadikan fisik sebagai bahan ejekan terhadap individu dalam kelompoknya. Bergosip mengenai kawan sebaya sering kali mendominasi percakapan di antara remaja (Buhrmester \& Chong dalam Santrock, 2012). Walaupun hanya dengan nada bercanda, body shaming dapat dikategorikan sebagai tindakan bullying karena dianggap sebagai bentuk kekerasan verbal terhadap orang lain (Sakinah, 2018).

Remaja perempuan yang belum memperlihatkan penerimaan terhadap dirinya, meyakini bahwa memiliki tubuh kurus akan membantunya dapat beradaptasi dengan lingkungan pergaulan di sekitarnya. Dengan begitu ia akan berupaya keras untuk melakukan diet meskipun dengan cara yang terbilang cukup ekstrim dan dapat membahayakan kesehatannya, bahkan lebih parahnya akan memunculkan kecenderungan anorexia nervosa (Ratnawati, dkk., 2012). Hal ini sejalan dengan penelitian yang dilakukan oleh Chairani (2018) yang menyebutkan bahwa terdapat korelasi tinggi antara body shaming dengan gangguan makan. Mereka akan berusaha melakukan usaha untuk mengurangi rasa malu, sesuatu yang membuat mereka menjadi objek body shaming. Penelitian lain dilakukan oleh Hidayat (2019) yang menunjukan terdapat hubungan yang signifikan antara body shaming dengan citra diri mahasiswa STIKes Payung Negeri yang menjadi responden penelitian tersebut, dimana para mahasiswa menganggap serius seseorang yang mengejek mereka gendut ataupun kurus sehingga mempengaruhi citra dirinya yang negatif dan menjadikan rasa tidak percaya diri, merasa malu, serta tidak mau makan.

Menurut American Psychiatric Assosiation (2015), anorexia nervosa adalah suatu kesalahan dalam memandang bentuk atau berat badan yang dimiliki. Seseorang yang mengalami gangguan ini memperlihatkan ketakutan berlebihan 
terhadap kenaikan berat badan, sehingga individu tersebut cenderung melakukan penolakan terhadap berat badan yang terbilang normal berdasarkan perhitungan Indeks Massa Tubuh (IMT). Anorexia nervosa (AN) ini sendiri merupakan salah satu jenis gangguan pola makan atau yang biasa disebut dengan eating disorder. Jenis-jenis lainnya meliputi bulimia nervosa $(B N)$, binge-eating disorder (BED), dan eating disorder not otherwise specified (EDNOS), pica dan rumination (American Psychiatric Association, 2013).

Munculnya perilaku makan menyimpang belum diketahui penyebabnya secara pasti karena bukan hanya terkait masalah kesehatan namun juga masalah psikis penderita. Penderita cenderung memiliki rasa kepercayaan diri yang rendah karena mereka merasa tidak memiliki bentuk tubuh yang kurus dan langsing (Eating Disorders Venture, 2006). Pendapat yang hampir sama juga disampaikan oleh Krisnani, dkk (2017) yang menyatakan bahwa faktor genetik, kepercayaan diri yang rendah, pola makan dan citra tubuh merupakan sebagian dari faktor penyebab dari pola makan yang menyimpang.

\section{Rumusan Masalah}

Berdasarkan pendahuluan diatas, maka dapat dirumuskan sebuah masalah yaitu: "apakah ada pengaruh body shaming terhadap kecenderungan anorexia nervosa pada remaja perempuan di Surabaya?".

\section{Landasan Teori}

Kecenderungan Anorexia Nervousa

Menurut Garner (dalam Murliana, 2019), kecenderungan anorexia nervosa merupakan suatu gejala tentang kekhawatiran tentang berat badan, bentuk tubuh, dan pola makan yang berhubungan erat dengan emosi berupa sikap, perasaan serta perilaku mengenai makan dan gejala gangguan makan. Anorexia nervosa juga memiliki ciri berupa gangguan yang terjadi pada individu yang menolak untuk mempertahankan berat badan normal minimal, kesalahan menginterpretasikan tubuh dan bentuknya, serta memiliki rasa takut yang hebat akan kenaikan berat badan. Aspek-aspek kecenderungan anorexia nervosa menurut Garner (dalam Murliana, 2019) antara lain: 


\section{a. Food Preocupation (Kecenderungan Makan)}

Suatu kondisi dimana seseorang memiliki perhatian yang lebih terhadap makanan. Dipenuhi juga oleh pikiran- pikiran terkait dengan makanan. Individu yang mengalami gejala ini merasa bahwa makanan telah mengendalikan dirinya. b. Body Image for Thinness (Citra Diri agar menjadi Kurus)

Individu memiliki pemikiran akan pentingnya body image dengan memiliki tubuh kurus. Selain itu individu memiliki ketakutan yang berlebihan apabila berat badannya mulai naik.

c. Vomiting and Lexating Abuse (Muntah dan Menyalahgunakan Obat Pencahar)

Individu akan melakukan berbagai macam hal agar berat badannya tetap terjaga. Cara yang diupayakan yaitu dengan menggunakan obat pencahar atau memuntahkan makanan.

d. Dieting (Diet)

Individu melakukan pembatasan - pembatasan dalam asupan dan jenis makanan yang dikonsumsi. Makanan yang dibatasi yaitu makanan yang memiliki banyak mengandung gula. Individu yang mengalami kecenderungan ini akan lebih memilih mengkonsumsi makanan yang memiliki sedikit kalori (diet food).

\section{e. Slow Eating (Makan Pelan)}

Seseorang mengkonsumsi makanan secara perlahan, itu dilakukan dengan harapan cepat merasa kenyang. Waktu yang dibutuhkan dalam menghabiskan makanan juga jauh lebih banyak daripada orang pada umumnya.

\section{Body Shaming}

Menurut Gilbert \& Miles (dalam Cahyani, R.R., 2018), body shaming merupakan pengalaman memalukan dapat difokuskan dari dalam diri yang meliputi perasaan malu, tingkah laku, perceived personality traits, ataupun keadaan pikiran. Adanya pengalaman memalukan dahulu yang menjadi identitas diri dan menjadi kenangan traumatis terkait dengan perasaan malu di masa depan serta mengakibatkan kerentanan yang traumatis, traumatis termasuk salah satu efek dari perlakuan body shaming tersebut (Matos, 2013). Aspek dari body shame menurut 
Gilbert \& Miles (dalam Cahyani, R.R., 2018) meliputi:

a Komponen Kognitif Sosial atau Eksternal

Kondisi ini mengacu pada pemikiran dari individu lain yang menilai dirinya sebagai seseorang yang kurang baik maupun rendah. Dia juga beranggapan orang lain melihat dengan rendah dirinya sehingga mengakibatkan menilai diri secara rendah.

b. Komponen Mengenai Evaluasi Diri Yang Berasal Dari Dalam

Mengacu pada pandangan terhadap diri sendiri yang kurang baik yang didasari dari pemikiran negatif mengenai diri sendiri. Hal ini terjadi karena adanya kritikan yang menyerang dengan kata-kata merendahkan diri sehingga mengakibatkan menurunnya tingkat kepercayaan diri individu dan menanamkan pemikiran malu juga dari dalam diri.

c. Komponen Emosi

Emosi yang terdapat dalam perasaan malu berupa perasaan marah, cemas, dan muak terhadap diri sendiri. Hal ini terjadi karena adanya pemikiran negatif atas dirinya sendiri serta ketidakmampuan mengikuti standar yang ada dari lingkungan.

d. Komponen Perilaku

Perasaan malu sehingga memunculkan kecenderungan untuk menghindar dari lingkungan sekitarnya. Adanya perasaan tidak nyaman yang timbul dari pandangan rendah dari orang sekitar sehingga merasa dirinya terancam.

e. Komponen Psikologis

Perasaan malu akan mengakibatkan seseorang merasa tertekan karena munculnya tuntutan untuk mampu sesuai dengan standar yang ada. Selain itu juga bodyshaming mampu mengakibatkan gangguan makan karena adanya keinginan untuk memiliki tubuh sesuai standart ideal lingkungan.

\section{Metode Penelitian}

Penelitian ini menggunakan pendekatan kuantitatif dengan jenis penelitian kausal, yaitu penelitian yang ingin melihat penyebab dari suatu variabel tertentu, hal-hal apa saja yang memengaruhi suatu variabel (Periantalo, 2016). Dalam 
variabel yang terlibat harus diidentifikasi secara jelas dan terukur, dengan menghubungkan antara variabel-variabel yang diteliti dinyatakan secara korelasional atau struktural dan diuji secara empirik.

Populasi yang digunakan dalam penelitian ini adalah remaja perempuan di kota Surabaya berusia 12 hingga 21 tahun yang mengalami kecenderungan anorexia nervosa dengan jumlah populasi yang tidak diketahui secara pasti. Jumlah sampel yang digunakan sebanyak 349 orang berdasarkan tabel penentuan jumlah sampel dengan taraf kesalahan sebesar 5\%, menurut Isaac \& Michael (dalam Sugiyono, 2012).

Instrumen yang digunakan dalam penelitian ini terdiri dari dua skala, yaitu skala kecenderungan anorexia nervosa dan skala body shaming yang dibuat sendiri oleh peneliti. Yang pertama yaitu skala kecenderungan anorexia nervosa terdapat 28 pernyataan dan diperoleh hasil sebanyak 22 pernyataan valid dengan indeks daya diskriminasi aitem $\left(\mathrm{r}_{1 \mathrm{x}}\right)$ yang cukup baik berkisar dari 0,274 - 0,775. Kemudian nilai Cronbach's Alfa sebesar 0,735 > 0,700, dengan demikian dapat dinyatakan bahwa skala kecenderungan anorexia nervosa tersebut reliabel.

Tabel 1

Blue Print Skala Kecenderungan Anorexia Nervosa

\begin{tabular}{|c|c|c|c|c|c|}
\hline \multirow{2}{*}{ Aspek-Aspek } & \multirow{2}{*}{ Indikator Perilaku } & \multicolumn{2}{|c|}{ Nomor Item } & \multirow{2}{*}{$\begin{array}{l}\text { Jumlah } \\
\text { Item }\end{array}$} & \multirow{2}{*}{ Bobot } \\
\hline & & $\mathbf{F}$ & $\mathbf{U}$ & & \\
\hline \multirow{2}{*}{$\begin{array}{l}\text { Food Preocupation } \\
\text { (Kecenderungan } \\
\text { Makan) }\end{array}$} & $\begin{array}{l}\text { Memiliki perhatian lebih } \\
\text { terhadap makanan }\end{array}$ & 1,15 & 8,22 & 4 & $14,2 \%$ \\
\hline & $\begin{array}{l}\text { Pikiran dikendalikan } \\
\text { oleh makanan. }\end{array}$ & 9,23 & 2,16 & 4 & $14,2 \%$ \\
\hline \multirow[t]{2}{*}{$\begin{array}{l}\text { Body Image for } \\
\text { Thinness (Citra Diri } \\
\text { untuk Kurus) }\end{array}$} & $\begin{array}{lr}\text { Pemikiran } & \text { akan } \\
\text { pentingnya citra } & \text { tubuh } \\
\text { yang tampak kurus } & \end{array}$ & 3,17 & 10,24 & 4 & $14,2 \%$ \\
\hline & $\begin{array}{lr}\text { Memiliki } & \text { ketakutan } \\
\text { berlebih } & \text { terhadap } \\
\text { kenaikan berat badan. }\end{array}$ & 11,25 & 4,18 & 4 & $14,2 \%$ \\
\hline $\begin{array}{l}\text { Vomiting and } \\
\text { Lexating Abuse } \\
\text { (Memuntahkan dan } \\
\text { Penyalahgunaan } \\
\text { Obat Pencahar) }\end{array}$ & \begin{tabular}{lr}
\multicolumn{2}{l}{ Melakukan berbagai } \\
macam upaya untuk \\
mempertahankan berat \\
badan dengan \\
menggunakan & obat \\
pencahar atau & atau \\
memuntahkan makanan
\end{tabular} & 5,19 & 12,26 & 4 & $14,2 \%$ \\
\hline Dieting (Diet) & $\begin{array}{lr}\text { Pembatasan } & \text { asupan } \\
\text { makanan } & \text { yang } \\
\text { dikonsumsi } & \\
\end{array}$ & 13,27 & 6,20 & 4 & $14,2 \%$ \\
\hline $\begin{array}{l}\text { Slow Eating (Makan } \\
\text { Pelan) }\end{array}$ & $\begin{array}{l}\text { Mengkonsumsi makanan } \\
\text { secara pelan }\end{array}$ & 7,21 & 14,28 & 4 & $14,2 \%$ \\
\hline \multicolumn{2}{|c|}{$\begin{array}{l}\text { Jumlah } \\
\end{array}$} & 14 & 14 & 28 & $100 \%$ \\
\hline
\end{tabular}


Skala kedua adalah skala body shaming dengan 24 pernyataan diperoleh hasil sebanyak 19 pernyataan valid dengan daya diskriminasi aitem $\left(\mathrm{r}_{1 \mathrm{x}}\right)$ yang cukup bagus pada kisaran angka 0,263 - 0,775. Sementara itu, untuk nilai Cronbach's Alfa sebesar 0,873 > 0,700, artinya bahwa skala body shaming tersebut reliabel.

Tabel 2

Blue Print Skala Body Shaming

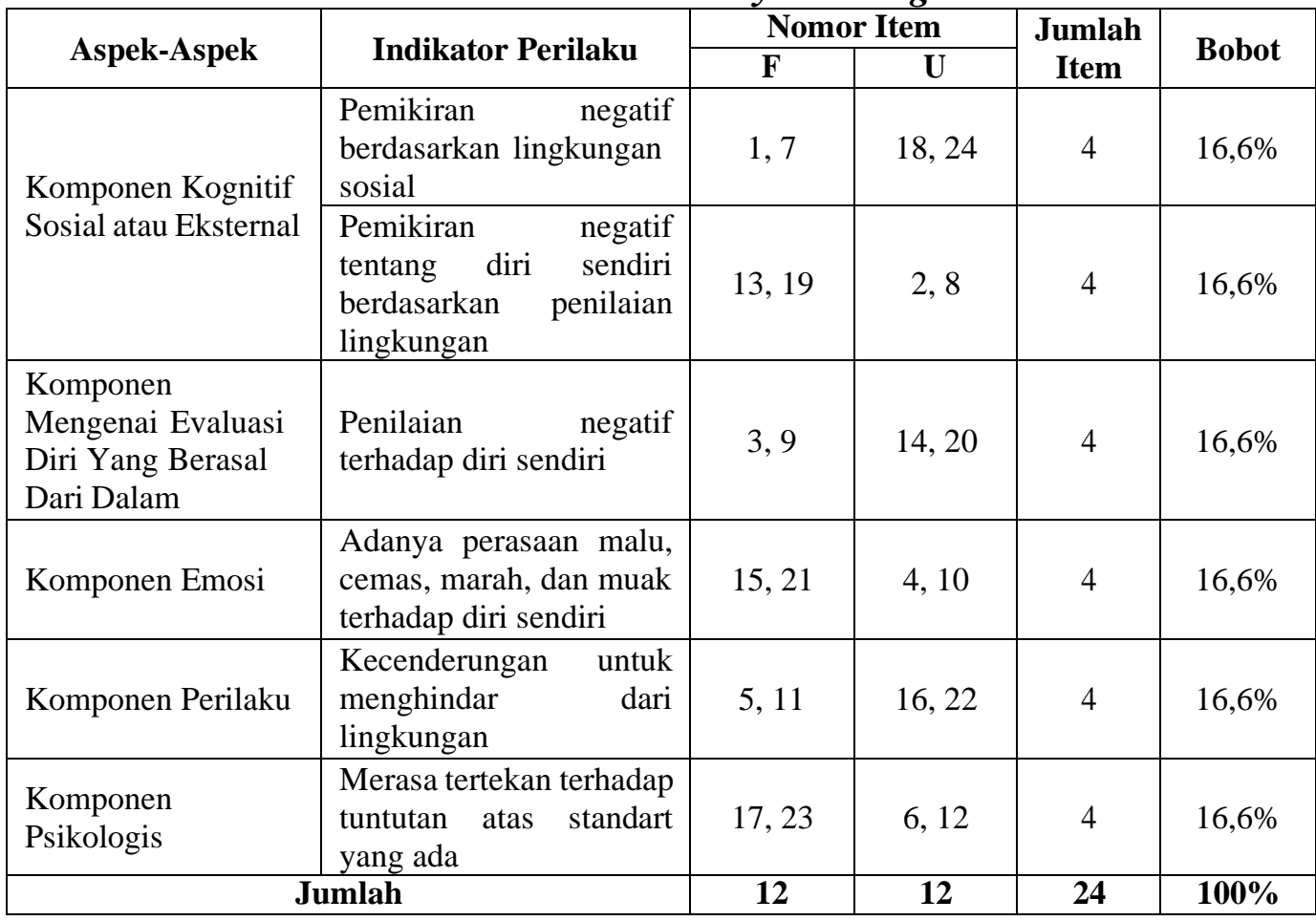

Sementara itu, untuk teknik analisa data yang digunakan dalam penelitian ini adalah regresi linier sederhana, dengan sebelumnya dilakukan beberapa uji asumsi yang dipersyaratkan, yaitu uji normalitas, uji heteroskedastisitas, dan uji linieritas. Selain itu, peneliti juga melakukan uji analisa deskriptif dan uji crosstabulation untuk menyajikan data variabel yang diteliti secara deskriptif.

\section{Hasil Penelitian}

\section{Uji Regresi Linier Sederhana}

Tabel 3

Model Summary

\begin{tabular}{|l|c|c|c|c|}
\hline \multicolumn{4}{|c|}{ Model Summary } \\
\hline Model & $\mathrm{R}$ & $\mathrm{R}$ Square & Adjusted R Square & Std. Error of the Estimate \\
\hline 1 & $.367^{\mathrm{a}}$ & $\mathbf{. 1 3 5}$ & .133 & 6.12098 \\
\hline \multicolumn{3}{|l}{ a. Predictors: (Constant), Body Shaming } \\
\hline
\end{tabular}


Korelasi antara variabel body shaming dengan kecenderungan anorexia nervosa berada dalam kategori cukup yaitu dengan nilai r sebesar 0,367. Sementara itu, nilai $R$ Square sebesar 0,135 atau sebesar 13,5\% (dari 0,135 x 100\%), dimana nilai tersebut merupakan kontribusi yang disumbangkan variabel $\mathrm{X}$ kepada $\mathrm{Y}$. Dengan demikian, dapat dikatakan bahwa body shaming mempengaruhi munculnya kecenderungan anorexia nervosa sebesar 13,5\% dan sisanya dipegaruhi oleh faktor lain selain body shaming.

\section{Tabel 4}

Anova

\begin{tabular}{|c|c|c|c|c|c|c|}
\hline \multicolumn{7}{|c|}{ ANOVA $^{\mathbf{a}}$} \\
\hline \multicolumn{2}{|c|}{ Model } & Sum of Squares & $\mathrm{df}$ & Mean Square & $\mathrm{F}$ & Sig. \\
\hline \multirow[t]{3}{*}{1} & Regression & 2029.632 & 1 & 2029.632 & 54.172 & $.000 \mathrm{~b}$ \\
\hline & Residual & 13000.838 & 347 & 37.466 & & \\
\hline & Total & 15030.470 & 348 & & & \\
\hline
\end{tabular}

Berdasarkan tabel di atas diperoleh nilai F 54,172 dengan signifikansi sebesar 0,000. Jika signifikansi < 0,05 maka hipotesis diterima karena 0,00 kurang dari $0,05(0,00<0,05)$. Artinya terdapat pengaruh body shaming terhadap kecenderungan anorexia nervosa.

\section{Uji Analisis Deskripsi dan Crosstabulation}

\section{Skala Anorexia Nervosa}

Berdasarkan perhitungan distribusi kurva dengan menggunakan rumus deviasi standar yang dikemukakan oleh Azwar (2015), diperoleh kategorisasi skala kecenderungan anorexia nervosa sebagai berikut:

Tabel 5

Kriteria Kategorisasi Skala Kecenderungan Anorexia Nervosa

\begin{tabular}{|c|c|c|c|}
\hline Skor & Kategori & Jml Subjek & Presentase \\
\hline $\mathrm{X} \geq 46,122$ & Tinggi & 34 & $9,7 \%$ \\
\hline $32,978 \leq \mathrm{X}<46,122$ & Sedang & 296 & $84,8 \%$ \\
\hline $\mathrm{X}<32,978$ & Rendah & 19 & $5,4 \%$ \\
\hline Jumlah & & 349 & $100 \%$ \\
\hline
\end{tabular}


Tabel 6

Crosstabulation Kategori Kecenderungan Anorexia nervosa dengan Usia

\begin{tabular}{|l|l|r|r|r|r|}
\hline \multicolumn{6}{|c|}{ Skor * Kelompok Umur Crosstabulation } \\
\hline \multirow{2}{*}{ Kategori } & & \multicolumn{2}{c|}{ Kelompok Umur } & \multirow{2}{*}{ Total } \\
\cline { 2 - 6 } & & $\mathbf{1 2 - 1 5}$ & $\mathbf{1 6 - 1 8}$ & $\mathbf{1 9 - 2 1}$ & \\
\hline \multirow{2}{*}{ Rendah } & Count & 1 & 12 & 19 & 32 \\
\cline { 2 - 7 } & Count & $3.1 \%$ & $37.5 \%$ & $59.4 \%$ & $100 \%$ \\
\hline \multirow{2}{*}{ Sedang } & $\%$ & $8.6 \%$ & $40.7 \%$ & $50.7 \%$ & $100 \%$ \\
\hline \multirow{2}{*}{ Tinggi } & Count & 1 & 19 & 17 & 37 \\
\cline { 2 - 6 } & $\%$ & $2.7 \%$ & $51.4 \%$ & $45.9 \%$ & $100 \%$ \\
\hline \multirow{3}{*}{ Total } & Count & 26 & 145 & 178 & 349 \\
\cline { 2 - 6 } & $\%$ & $7.4 \%$ & $41.5 \%$ & $51.0 \%$ & $100 \%$ \\
\hline
\end{tabular}

Diketahui bahwa dari 349 remaja perempuan di Surabaya memiliki tingkat kecenderungan anorexia nervosa kategori tinggi sebesar 9,7\%, berjumlah 34 orang. Pada kategori sedang sebesar 84,8\%, berjumlah 296 orang. Sedangkan responden pada kategori rendah sebesar 5,4\% sebanyak 19 orang. Pada pengkategorisasian kecenderungan anorexia nervosa dengan pengelompokan berdasarkan usia dapat diketahui bahwa responden remaja akhir berusia 19-21 tahun merupakan responden mayoritas yaitu 178 orang atau 51,0\%. Dengan responden yang mendapatkan skor tinggi sebanyak 17 orang atau 45,9\%, lalu pada responden yang mendapatkan skor sedang 142 orang atau $50,7 \%$, dan pada responden yang mendapatkan skor rendah adalah 19 orang atau 59,4\%. Berdasarkan usia remaja pertengahan atau direntang usia 16-18 tahun, responden sebanyak 145 orang atau 41,5\% dari keseluruhan responden. dengan responden yang mendapatkan skor tinggi sebanyak 19 orang atau $51,4 \%$, sedang 114 orang atau $40,7 \%$, dan 12 orang atau 37,5\%. Sedangkan pada usia remaja awal atau direntang usia 12-15 tahun, responden yang memiliki skor tinggi sebanyak 1 orang atau 2,7\%, sedang 24 orang atau 8,6\%, dan rendah sebanyak 1 orang atau $3,1 \%$.

Tabel 7

Kriteria Kategorisasi Skala Body Shaming

\begin{tabular}{|c|c|c|c|}
\hline Skor & Kategori & $\begin{array}{c}\text { Jml } \\
\text { Subjek }\end{array}$ & Presentase \\
\hline$X \geq 46,294$ & Tinggi & 58 & $16,6 \%$ \\
\hline $30,406 \leq X<46,294$ & Sedang & 253 & $72,4 \%$ \\
\hline$X<30,406$ & Rendah & 38 & $10,8 \%$ \\
\hline \multicolumn{2}{|c|}{ Jumlah } & 349 & $100 \%$ \\
\hline
\end{tabular}


Tabel 8

Crosstabulation Kategori Body Shaming dengan Usia

\begin{tabular}{|c|l|r|r|r|r|}
\hline \multicolumn{6}{|c|}{ Skor * kelompok umur Crosstabulation } \\
\hline \multicolumn{2}{|c|}{ Kategori } & \multicolumn{3}{|c|}{ kelompok umur } & Total \\
\cline { 3 - 7 } \multicolumn{2}{|c|}{} & $\mathbf{1 2 - 1 5}$ & $\mathbf{1 6 - 1 8}$ & $\mathbf{1 9 - 2 1}$ & \\
\hline \multirow{3}{*}{ Rendah } & Count & 1 & 15 & 29 & 46 \\
\cline { 2 - 6 } & $\%$ & $2.2 \%$ & $32.6 \%$ & $63.0 \%$ & $100 \%$ \\
\hline \multirow{3}{*}{ Sedang } & Count & 19 & 92 & 134 & 245 \\
\cline { 2 - 7 } & $\%$ & $10.3 \%$ & $60.3 \%$ & $54.7 \%$ & $100 \%$ \\
\hline \multirow{3}{*}{ Tinggi } & Count & 6 & 35 & 16 & 58 \\
\cline { 2 - 7 } Total & $\%$ & $7.8 \%$ & $37.6 \%$ & $27.6 \%$ & $100 \%$ \\
\cline { 2 - 7 } & Count & 26 & 142 & 179 & 349 \\
\hline \multirow{2}{*}{} & & $7.4 \%$ & $40.7 \%$ & $51.3 \%$ & $100 \%$ \\
\hline
\end{tabular}

Pada tabel kriteria kategorisasi skala body shaming, diketahui bahwa dari 349 remaja perempuan di Surabaya memiliki tingkat body shaming kategori tinggi sebesar $16,6 \%$ atau sebanyak 38 orang. Pada kategori sedang sebesar $72,4 \%$ atau sebanyak 253 orang. Sedangkan pada kategori rendah sebesar 10,8\% atau sebanyak 58 orang. Pada pengkategorisasian sebanyak 134 orang atau 54,7\%, dan pada responden yang mendapatkan skor rendah adalah sebanyak 29 orang atau 63,0\%. Berdasarkan usia remaja pertengahan atau direntang usia 16-18tahun, responden sebanyak 142 orang atau 40,7\% dari keseluruhan responden. Dengan responden yang mendapatkan skor tinggi sebanyak 35 orang atau 37,6\%, sedang 92 orang atau $60,3 \%$, dan rendah 15 orang atau 32,6\%. Sedangkan pada usia remaja awal berkisar usia 12-15 tahun sebanyak 26 orang atau 7.4\%. dengan responden yang mendapatkan skor tinggi sebanyak 6 orang atau 7,8\%, sedang 19 orang atau 10,3\%, dan rendah sebanyak 1 orang atau 2,2\%.

\section{Pembahasan}

Berdasarkan hasil uji regresi sederhana yang telah dilakukan terdapat pengaruh body shaming terhadap kecenderungan anorexia nervosa pada remaja perempuan di Surabaya dengan korelasi keeratan dalam kategori cukup. Dalam hasil penelitian ini, remaja perempuan yang mengalami body shaming tinggi menyebabkan dirinya mengalami kecenderungan anorexia nervosa atau dapat dikatakan semakin tinggi body shaming maka semakin tinggi pula tingkat kecenderungan anorexia nervosa yang dialami. 
Hal ini disebabkan oleh cara berpikir remaja yang menjadi lebih abstrak dan idealistik serta diiringi dengan perubahan tubuh yang terjadi menjadi pemicu minat terhadap citra tubuh. Akibatnya, dengan adanya body image ini dapat memungkinkan seseorang untuk melakukan pembandingan keadaan antara dirinya dengan orang lain sehingga menimbulkan rasa malu terhadap tubuhnya sendiri, yang biasa disebut dengan istilah body shame (Damanik, 2018). Remaja perempuan yang merasa kurang mampu menerima diri apa adanya, dengan beranggapan bahwa memiliki tubuh kurus akan lebih mudah beradaptasi dengan lingkungan pergaulan disekitarnya, menjadikan sebagai tantangan untuk melakukan diet walaupun dengan cara ekstrim yang dapat membahayakan kesehatannya dan menimbulkan kecenderungan anorexia nervosa (Ratnawati, Dkk., 2012).

Menerima kondisi fisik dan memanfaatkannya secara efektif merupakan tugas perkembangan yang harus diselesaikan dengan baik oleh remaja (Ali \& Asrori, 2012). Secara hakikatnya, remaja menjadi bangga atau setidaknya toleran dengan kondisi fisiknya sendiri, menjaga dan melindungi, serta menggunakannya secara efektif. Namun bagi remaja perempuan yang memiliki citra tubuh negatif dan cenderung kurang puas dengan kondisi tubuhnya akan melakukan penilaian negatif terhadap tubuhnya tersebut, baik berdasarkan penilaiannya sendiri maupun penilaian dari orang lain. Bagi mereka yang memilih memperbaiki penampilan dengan sengaja menahan lapar atau tidak makan dapat menyebabkan munculnya kecenderungan anorexia nervosa. Sebagaimana studi yang dilakukan oleh Chairiah (2012) tentang hubungan antara citra tubuh dan pola makan pada remaja perempuan menunjukkan bahwa seorang remaja cenderung menjaga pola makan untuk mendapatkan tubuh yang ideal, sehingga apabila semakin positif citra tubuh seseorang (ideal), maka pola makan akan semakin baik dan teratur.

Adapun salah satu faktor yang mempengaruhi gangguan makan ini dalam kehidupan seseorang yaitu adanya media massa yang berperan sangat besar dalam menyebarkan informasi mengenai standar tubuh yang ideal, baik majalah, televisi, dan situs di internet, sehingga mempengaruhi ketidakpuasan subjek melalui tokoh idola atau model yang memiliki tubuh kurus dan pakaian-pakaian yang ditampilkan di media massa (Purba, 2012). Dengan demikian mereka rela melakukan diet ketat untuk mengurangi rasa malu karena body shaming. Perilaku makan menyimpang 
seperti anaorexia nervosa dan bulimia nervosa masih sering dianggap sebagai sindrom yang terikat dengan budaya, yaitu bahwa hanya dialami oleh masyarakat negara barat karena selama ini laporan mengenai perilaku makan menyimpang hanya berasal dari negara barat. Padahal beberapa tahun belakangan ini perilaku makan menyimpang juga mulai terjadi pada masyarakat Asia, terutama dengan makin gencarnya pemasaran produk-produk kecantikan dan pakaian-pakaian bergaya luar negeri yang menjual kecantikan ala barat pada pasar Asia (Tantiani \& Syafiq, 2008). Sebagai negara Asia, masyarakat Indonesia juga menggunakan pencitraan tubuh ideal wanita Barat sebagai kiblat gaya hidup. Hal ini kemudian mengarahkan seorang remaja untuk mulai memperhatikan bentuk tubuh ideal sesuai dengan standar yang ada dalam masyarakat.

Sementara itu dari pengolahan data penelitian didapatkan kontribusi atau sumbangan efektif antara body shaming terhadap kecenderungan anorexia nervosa dapat diketahui dengan melihat nilai R square sebesar 0,135 (13,5\%), dimana nilai tersebut merupakan nilai kontribusi yang disumbangkan oleh variabel $\mathrm{X}$ yaitu body shaming kepada variabel Y yaitu kecenderungan anorexia nervosa. Sedangkan $86,5 \%$ lainnya dipengaruhi oleh faktor lain yang tidak diteliti dalam penelitian ini.

Menurut Davison et.al (2010) gangguan makan tidak dapat berkembang karena adanya faktor tunggal yang menjadi penyebabnya, terdapat beberapa faktor yang mempengaruhi gangguan makan dalam kehidupan seseorang, meliputi faktor biologis, psikologis, keluarga dan sosio-kultural. Faktor biologis artinya anorexia nervosa dapat terjadi dalam satu keluarga, kerabat tingkat pertama dari wanita yang menderita anorexia nervosa memiliki kemungkinan sepuluh kali lebih besar, serta adanya ketidakseimbangan yang mungkin terjadi pada sistem neurotransmitter di otak yang berguna untuk mengatur mood dan nafsu makan.

Kedua, faktor psikologis yaitu berupa diet yang kaku, ketidakpuasan pada tubuh, dll. Ketiga, faktor keluarga dari pasien gangguan makan yang memiliki karakteristik yang sama dan disfungsional keluarga. Terakhir yaitu faktor sosiokultural yang berlebihan pada wanita yang ingin mencapai standart kurus yang tidak realistis. Berat badan normal sesuai usianya masih dianggap gemuk bagi dirinya maupun orang lain sampai berat badan tersebut benar-benar berada di bawah normal. Mereka mengacu pada standart tubuh ideal yang ditampilkan di media. 


\section{Kesimpulan dan Saran}

Berdasarkan penelitian diatas, maka dapat disimpulkan bahwa:

1. Hasil uji regresi linier sederhana yang telah dilakukan menunjukkan bahwa $F$ hitung sebesar 54,172 dengan taraf signifikansi sebesar 0,00. Nilai tersebut lebih kecil dari 0,05 $(0,00<0,05)$, sehingga hipotesis diterima, yaitu terdapat pengaruh antara body shaming terhadap kecenderungan anorexia nervosa pada remaja perempuan di kota Surabaya.

2. Nilai koefisien korelasi (r) sebesar 0,367 dapat diidentifikasikan bahwa antara variabel X dan Y terdapat korelasi dengan kategori cukup.

3. Nilai koefisien determinasi (R Square) sebesar 0,135 (13,5\%), dimana nilai tersebut merupakan kontribusi yang disumbangkan variabel body shaming terhadap variabel kecenderungan anorexia nervosa. Dengan demikian body shaming memiliki pengaruh terhadap kecenderungan anorexia nervosa sebesar $13,5 \%$, sedangkan $86,5 \%$ lainnya dipengaruhi oleh faktor lain yang tidak diteliti oleh peneliti.

4. Dari hasil kategorisasi, remaja yang mempunyai kecenderungan anorexia nervosa dan mengalami body shaming lebih didominasi pada remaja akhir yang berusia 19-21 tahun dengan mayoritas kategori sedang.

\section{DAFTAR PUSTAKA}

Ali, M. \& Asrori, M. (2012). Psikologi Reamaja Perkembangan Peserta Didik. Jakarta: PT Bumi Aksara

American Psychological Association (APA). (2015). APA dictionary of psychology, second edition. Washington DC: American Psychological Association.

American Psychological Association. (2013). Diagnostic and Statiztical Manual of mental disorders (DSM-5), fifth edition. Washington DC: American Psychological Association.

Arcelus, J., Mitchell, A.J., \& Wales, J. (2011). Mortality rates in patients with anorexia nervosa and other eating disorders. Archives of General Psychiatry, 68(7), 724-731.

Cahyani, R.R. (2018). Efektivitas Cognitive Behavior Therapy untuk Menurunkan Tingkat Body Shaming. Skripsi, Fakultas Psikologi Universitas Islam Negeri Maulana Malik Ibrahim, Malang. 
Chairani, L. (2018). Body Shame dan Gangguan Makan Kajian Meta-Analisis. Buletin Psikologi. Diterbitkan. Pekanbaru: UIN Suska Riau, 26(1), 12-27.

Chairiah, P. (2012). Hubungan Gambaran Body Image Dan Pola Makan Remaja Putri Di SMAN 38 Jakarta. Skripsi, Fakultas Ilmu Keperawatan Universitas Indonesia, Depok.

Chandra, F. O. \& Mulya, T. W. (2009). Perilaku Pembulian pada Siswa SMA di Surabaya. Indonesian Psychological Journal. 24 (4), 348-364.

Christiani, Lintang C. (2015). Homogenisasi Tubuh Perempuan Pra-Remaja (Tween) Dalam Majalah Girls. Tesis, Magister Ilmu Komunikasi Universitas Diponegoro, Semarang.

Davison, at. Al. (2010). Psikologi Abnormal Edisi Ke-9. Jakarta: PT Raja Grafindo Persada.

Damanik, T. M. (2018). Dinamika Psikologis Perempuan Mengalami Body Shaming. Skripsi, Program Studi Psikologi Fakultas Psikologi Universitas Sanata Dharma, Yogyakarta.

Fauzia, T. F. (2019). Memahami Pengalaman Body Shaming pada Remaja Perempuan. Jurnal Departemen Ilmu Komunikasi Universitas Diponegoro.

Guindon, M. H. (2010). Self-esteem ascross the lifespan. New York: Routledge.

Krisnani, H., Santoso, M.B. \& Putri, D. (2017). Gangguan Makan Anorexia Nervosa dan Bulimia Nervosa pada Remaja. Prosiding Penelitian \& Pengabdian Masyarakat, 4 (3).

Matos. (2013). Internalizing Early Memories of Shame and Lack of Safeness and Warmth: The Mediating Role of Shame on Depression. Behavioural and Cognitive Psychotherapy, 41 (4).

https://doi.org/10.1017/S1352465812001099

Murliana. (2019). Hubungan Antara Kecenderungan Gangguan Anorexia Nervosa dengan Kecenderungan Body Dysmorphic Disorder pada Siswa SMAN 02 Sidoarjo yang Mengikuti Ekstrakurikuler Dance. Skripsi, Fakultas Psikologi Islam Negeri Sunan Ampel Surabaya. Neuman, W. L. 2016). Metodologi Penelitian Sosial, Pendekatan Kualitatif dan Kuantitatif Edisi 7.

Periantalo, J. (2016). Penelitian Kuantitatif untuk Psikologi. Yogyakarta: Pustaka Pelajar.

Sugiyono. (2012). Metode Penelitian Pendidikan Pendekatan Kuantitatif dan Kualitatif dan $R \& D$. Bandung: Alfabeta. 
Ratnawati, V. \& Sofiah, D. (2012). Percaya Diri, Body Image dan Kecenderungan Anorexia Nervosa pada Remaja Putri. Persona Jurnal Psikologi Indonesia, 1 (2)

Sakinah. (2018). “Ini Bukan Lelucon”: Body Shaming, Citra Tubuh, Dampak dan Cara Mengatasinya. Jurnal Emik: Universitas Hasanuddin, 1(1), 53-66.

Santrock, J. W. (2011). Life-Span Development-Perkembangan Masa Hidup Jilid I (Edisi 13). Jakarta: Erlangga.

Santrock, J. W. (2012). Perkembangan Masa Hidup Jilid II (Edisi Ke-13). Jakarta: Erlangga.

Tantiani \& Syafiq. (2008). Perilaku Makan Menyimpang pada Remaja di Jakarta. Tesis. Program Pascasarjana FKM UI, Jakarta.

Widiasti, Ni Luh R. (2016). Profil Citra Tubuh (Body Image) pada Remaja dan Implikasinya Bagi Bimbingan dan Konseling. Skripsi, Departemen Psikologi Pendidikan dan Bimbingan FIP Universitas Pendidikan Indonesia, Bandung. 